disease in their hosts. This theory postulates that HIV has recently evolved from a non-pathogenic human ancestor lentivirus which would have had to be sufficiently different not to induce antibodies reactive in standard HIV tests or to have been confined until recently to small remote populations. These possibilities are not mutually exclusive. To date there is no evidence for such a "missing link." The serological and molecular techniques used to look for viruses like HIV in normal subjects may not, however, reliably detect even quite close ancestors. Occasionally antibodies to HIV core proteins are found in normal subjects, ${ }^{21}$ which might point to the existence of an unknown human lentivirus-but this is speculative.

If HIV was transmitted to man from monkeys how could this have happened? Transmission might have been possible through bites, scratches, medicines, or ritual preparations obtained from other primates. Irrespective of whether HIV was transmitted to humans from primates or whether it evolved from an ancestor lentivirus in man, when could this have happened? The earliest retrospectively identified cases of AIDS occurred in the 1960s, ${ }^{22}{ }^{23}$ and a comparison of the genomic sequence variability among several strains of HIV-I,

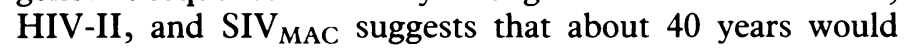
have been long enough for the differences observed between HIV-I and HIV-II to have evolved. ${ }^{2+25}$ It is therefore possible, but by no means certain, that HIV evolved towards becoming a pathogenic virus or spread into human populations, or both, within the past few decades.

Where did HIV come from? Very early cases of AIDS (retrospectively identified) seem to have originated in Africa. ${ }^{22} 23$ There have been unconfirmed reports that related viruses may occur in other parts of the world. The extent to which rapid political, social, and cultural changes that have occurred in African society during this century could have played a part in the spread of HIV is impossible to specify, although some of the features of the AIDS epidemic - for example, its spread through prostitution - are certainly linked to rapid urbanisation.

The origin of HIV remains a mystery. Attempts to solve it may disclose information about the evolution of lentiviruses in different species and, perhaps, lead to the discovery of as yet unknown lentiviruses in humans. The future prevention of AIDS is the real challenge, but understanding the origins of
HIV and the reasons why simian immunodeficiency viruses are not pathogenic in their natural hosts may eventually help in controlling HIV.

We acknowledge the help of Professor Robin A Weiss, director of the Institute of Cancer Research, in preparing this article.

MYRA O MCCLURE

Institute of Cancer Research, THOMAS F SCHULZ

Chester Beatty Laboratories,

London SW3 6BJ

1 Weiss R, Teich N, Varmus H, Coffin J. Molecular biology of tumor viruses. 2nd ed. New York: Cold Spring Harbor Laboratory, 1982

2 Wain-Hobson S, Sonigo P, Danos O, Cole S, Alizon M. Nucleotide sequence of the Visna lentivirus: relationship to the AIDS virus. Cell 1985;40:9-17.

3 Haase AT. Pathogenesis of lentivirus infections. Nature 1986;322:130-6.

4 Chiu I-M, Yaniv A, Dahlberg JE, et al. Nucleotide sequence evidence for relationship of AIDS retrovirus to lentiviruses. Nature 1986;317:366-8.

Daniel MD, Letvin NL, King NW, et al. Isolation of a T-cell tropic HTLV-III like retrovirus from macaques. Science 1985;228:1201-4.

6 Kestler HW, Li Y, Naidu YM, et al. Comparison of simian immunodeficiency virus isolates. Nature 1988;331:619-21.

7 Chakrabarti L, Guyader M, Alizon M, et al. Sequence of Simian immunodeficiency virus from macaque and its relationship to other human and Simian retroviruses. Nature 1987;328:543-7.

8 Benveniste RE, Arthus LO, Tsai C-C, et al. Isolation of a lentivirus from a macaque with lymphoma: comparison with HTLV-IIL/LAV and other lentiviruses. $f$ Virol 1986;60:483-90.

Daniel MD, Letvin NL, Seghal PK, et al. Prevalence of antibodies to three retroviruses in a captive colony of macaque monkeys. Int $\mathcal{f}$ Cancer 1988;41:601-8.

10 Murphy-Corb M, Martin LN, Rangan SRS, et al. Isolation of an HTLV-III related retrovirus from macaques with simian AIDS and its possible origin in asymptomatic mangabeys. Nature 1986;321:435-7.

11 Fultz PN, McClure HM, Anderson DC, Swenson RB, Anand R, Srinivasan A. Isolation of a $\mathrm{T}$-lymphotropic retrovirus from naturally infected sooty mangabey monkeys (Cercocebus atys). Proc Natl Acad Sci USA 1986;83:5286-90.

12 Fukasawa $M$, Miura $T$, Hasegawa $A$, et al. Sequence of simian immunodeficiency virus from African green monkey, a new member of the HIV/SIV group. Nature 1988;333:457-61.

13 Daniel MD, Li Y, Naidu YM, et al. Simian immunodeficiency virus from African green monkeys. f Virol 1988;62:4123-8.

14 Ohta $\mathrm{Y}$, Massuda T, Tsujimoto $\mathrm{H}$, et al. Isolation of simian immunodeficiency virus from African green monkey and seroepidemiologic survey of the virus in various non-human primates. Int $\mathcal{F}$ Cancer 1988;41:115-22.

15 Tsujimoto H, Cooper RW, Kodama T, et al. Isolation and characterisation of simian immunodeficiency virus from mandrills in Africa and its relationship to other human and simian immunodeficiency viruses. I Virol 1988;62:4044-50.

$16 \mathrm{Li} \mathrm{Y}$, Naidu YM, Daniel MD, Desrosiers RC. Extensive genetic variability of simian immunodeficiency virus from African green monkeys, $\mathcal{f}$ Virol (in press).

17 Toh H, Miyata Y. Is the AIDS virus recombinant? Nature 1985;316:21-2.

18 Fine D, Schochetman G. D-type retroviruses: a review. Cancer Res 1978;38:3123-39.

19 Barbacid M, Long LK, Aaronson SA. Major structural proteins of type B, type C and type D oncoviruses share interspecies antigenic determinants. Proc Natl Acad Sci USA 1980;77:72-6.

20 Sonigo P, Barker C, Hunter E, Wain-Hobson S. Nucleotide sequence of Mason-Pfizer monkey virus: an immunosuppressive D-type retrovirus. Cell 1986;45:375-85.

21 Bibefeld G, Bredberg-Raden U, Bottiger B, et al. Blood donor sera with false positive Western blot reactions to human immunodeficiency virus. Lancet 1986;ii:289-90.

22 Froland SS, Jenum P, Lindboe CF, Wefring KW, Linnestad PJ, Bohmer T. HIV-1 infection in Norwegian family before 1970 . Lancet $1988 ; \mathrm{i}: 1344-5$.

23 Kawamura M, Yamazaki S, Ishikawa K, et al. HIV-2 in West Africa. Lancet 1989;i:385.

24 Smith TF, Srinivasan A, Schochetman G, Marcus M, Myers G. The phylogenetic history of immunodeficiency viruses. Nature 1988;333:573-5.

25 McClure MA, Johnson MS, Feng D-F, Doolittle RF. Sequence comparisons of retroviral proteins: relative rate of change and general phylogeny. Proc Natl Acad Sci USA 1988;85:2469-73.

\title{
Institutional review boards
}

\section{Britain should consider the US example of more controlled ethics committees}

The American counterpart to the British research ethics committee is the institutional review board. The principal function of these committees is to review proposals to conduct research in humans to assure conformity with ethical standards. Although the leading international code of research ethics, the World Medical Assembly's Declaration of Helsinki, charges these bodies to provide only "consideration, comment, and guidance," in both the United States and the United Kingdom they have the authority to approve or disapprove plans to conduct research.

Although the goals of ethical review in the United States and Britain are identical, there are some striking contrasts in the means employed to pursue them. In the United States, but not in Britain, ethical review and approval is required by national law for most types of clinical research; virtually all research institutions have negotiated agreements with the federal government that extend the requirement for ethical review to all clinical research. ${ }^{1}$ Federal regulations specify minimum requirements for membership, functions, and operations of the institutional review board.

The ethical criteria for approval of research by institutional review boards are set forth in considerable detail in federal regulations. The review boards have the authority to monitor the conduct of research to assure compliance with ethical standards; if they detect either non-compliance or "unexpected serious harm to subjects" they are empowered to suspend or terminate the research. By regulation, institutional review boards are required to report to institutional officials and to the federal government "any serious or continuing noncompliance by investigators" with the boards' requirements.

Applications to the United States Department of Health and Human Services for grants or contracts to support 
research in human subjects must be reviewed and approved by the local institutional review board before the Department of Health and Human Services will even consider whether they should be funded. Nevertheless, by regulation, the Department of Health and Human Services is required to repeat some of the institutional review board's activities; for example, the department must repeat the evaluation of the relation between risks and benefits. The institutional review board does not have the authority to approve certain categories of research specified in the regulations-for example, research in children in which "more than minor increases over minimal risk" are presented by "an intervention or procedure that does not hold out the prospect of direct benefit" for the child subject. Research in these categories can be approved only by the secretary of the Department of Health and Human Services in consultation with a panel of experts and after an opportunity for review and comment by the public. To the best of my knowledge there are no similar activities at national level in the United Kingdom, although they have been advocated by Mary Warnock and others. ${ }^{2}$

Agents of the United States Food and Drug Administration conduct routine inspections of the institutional review boards and investigators engaged in the review or conduct of research on drugs, medical devices, and other "test articles" regulated by the administration. Inspections by officials of the United States Department of Health and Human Services may also occur in response to reports of "serious or continuing noncompliance."

Federal regulations require that each institutional review board should have "at least one member who is not otherwise affiliated with the institution." Many states require public institutions to open their meetings to the public, and some private institutions similarly open their meetings. Though few "outsiders" seem to attend meetings of the institutional review boards, these policies serve to remind the members of their ultimate accountability to the public. Spokespersons for institutional review boards engaged in reviewing activities of great interest to the media - for example, the implantation of a baboon's heart in "Baby Fae"3 and of the first totally artificial heart ${ }^{4}$-have reported that the presence of journalists has been highly disruptive.

In response to apparent ethical improprieties in the conduct of clinical research several British commentators-for example, Byrne, ${ }^{5}$ Faulder, ${ }^{6}$ and Nicholson ${ }^{7}$ - have called for reform in the British system of ethical oversight in research. In their view Britain should adopt a system similar to that in place in the United States. Elsewhere I have suggested that the American system of regulation reflects its unique recent social history and distinctively individualistic ethos. ${ }^{8}$ For this reason other societies may find some of the United States' policies and practices unsuitable for their needs.

Professor of Medicine,

ROBERT J LEVINE

Yale University School of Medicine

New Haven, Connecticut 06510,

United States

1 Levine RJ. Ethics and regulation of clinical research. 2nd ed. Baltimore: Urban and Schwarzenberg, 1986.

Warnock M. A national ethics committee. Br Med f 1988;297:1626-7.

3 Sheldon R. The IRB's responsibility to itself. Hastings Center Report 1985;15:11-2.

4 Working Group on Mechanical Circulatory Support of the National Heart, Lung, and Blood Institute. Artificial heart and assist devices: directions, needs, costs, societal and ethical issues. Institute. Artificial heart and assist devices: directions, needs,

5 Byrne P. Medical research and the human subject: problems of consent and control in the UK experience. Ann NY Acad Sci 1988;530:144-53.

6. Whose 1985.

Nicholson RH, ed. Medical research with children. Oxford: Oxford University Press, 1986.

8 Levine RJ. Protection of human subjects of biomedical research in the United States: a contrast with recent experience in the United Kingdom. Ann NY Acad Sci 1988;530:133-43.

\title{
The contraceptive pill and breast cancer in young women
}

\author{
Evidence is still reassuring
}

Last week saw yet more press headlines about the contraceptive pill and breast cancer. Yet as the number of epidemiological studies on the effect of oral contraceptives on breast cancer has increased the picture remains far from clear. This lack of consensus contrasts with other studies on the contraceptive pill. For example, at least nine case-control studies have agreed that combined oral contraceptives reduce the risk of endometrial cancer, and at least eight case-control studies have shown a reduced risk of ovarian cancer. ${ }^{1}$ A protective effect against uterine and ovarian cancers is biologically plausible because combined oral contraceptives abolish the rapid cellular proliferation that occurs every month in these organs.

An effect of combined oral contraceptives on the incidence of breast cancer is also biologically plausible. The fact that the risk of breast cancer is increased by an early menarche and by a late menopause ${ }^{1}$ implicates ovarian steroids in the initiation or promotion, or both, of breast cancer. What is far from clear on theoretical grounds is whether combined oral contraceptives can be expected to enhance or to antagonise these harmful effects of ovarian activity. The ovary produces its hormones sequentially - first oestrogen then progesterone-but combined oral contraceptives provide them simultaneously. If unopposed oestrogen is a risk factor for breast cancer (as it is for endometrial cancer) combined oral contraceptives should diminish breast cancer risk, but no such effect has been observed in epidemiological studies. Breast lobules do not proliferate during the menstrual cycle, but cell turnover increases in the second half of the cycle..$^{3-5}$ The pattern of cell turnover in the breast is not affected by combined oral contraceptives. ${ }^{45}$

The theoretical uncertainty has been reflected by conflicting results from epidemiological studies. Of the many studies published so far, none has suggested that combined oral contraceptives protect against breast cancer and most have failed to show any effect of combined oral contraceptives on the risk of breast cancer. ${ }^{6-9}$ Some have shown an increased risk associated with the use of the contraceptive pill early in life or before the first pregnancy while showing no risk associated with the use of combined oral contraceptives later in the reproductive years. ${ }^{6}{ }^{10}$ Studies which have concluded that the use of combined oral contraceptives carries risks tend to have been scrutinised more critically than those with reassuring results, but in general both studies giving negative results and those giving positive results have been conducted with equal care and there is no obvious explanation for their different results. ${ }^{1671112}$

Last week saw the publication in the Lancet of a.casecontrol study in 11 areas of Britain of 755 women with breast cancer that had been diagnosed before the age of $36 .{ }^{13}$ Cases 